\title{
Fishery and its Management of Sugaon Lake of East Champaran District of Bihar, India
}

\author{
Kumari Priyanka ${ }^{1}$, Neha Raj $^{2}$ and Safal Kumar Mishra ${ }^{1 *}$ \\ ${ }^{1}$ Department of Zoology, B. R. A. Bihar University, India \\ ${ }^{2}$ Department of Zoology, P. K. University, India \\ *Corresponding Author: Safal Kumar Mishra, Department of Zoology, \\ B. R. A. Bihar University, India.
}

Received: August 27, 2021;

Published: September 23, 2021

(C) All rights are reserved by Safal Kumar

Mishra., et al.

\begin{abstract}
A remarkable physical feature of East Champaran district of Bihar is a chain of lakes, running through the centre of the district. These lakes of which the largest one at Chaknaha, Piprapakri, Bakaya, Kararia, Motijheel, Turkaulia, Sugaon, Phulwari, Sirsa, Chilraon, etc., evidently mark an old bed of the river Great Gandak. Lakes are of natural origin and because of their magnitude as well as production potential occupy important position in Indian inland fisheries. There is a high rate of primary production in the lakes of plains which suggests that if scientifically managed, the fish production can be augmented to a greater extent.

Ichthyologically the condition of Sugaon lake has been deteriorating under the impact of anthropogenic pressure, global warming and fast pace of development and if proper conservative measures are not taken the lake is likely to further deteriorate.
\end{abstract}

Keywords: Fishery; Management; Sugaon Lake; East Champaran; Bihar

\section{Abbreviation}

Sq.: Square; N: North; E: East; ha: Hectare; spp: Species

\section{Introduction}

The word 'Lake' comes from the Greekword 'Lakkos' meaning hole or pond (a basin), formed on the surface of earth due to various natural mechanisms. The lakes are variously termed as 'Jheel'; 'Beel'; 'Bellabongs' in Australia; 'Lores' in France and 'Altwasser' in Germany. In study area lakes are termed as 'Maun' and 'Jheel' respectively. Lakes has been classified on the basis of chemistry, physical form, size, geographical position, depth, phytoplankton, zooplanakton, macrophytes, invertebrates, fish, human use etc. A. Forel (1901) Father of Limnology, gave the first generally accepted systems of classification on the basis of thermal characteristics and recognized three types of lakes viz. Polar, Temperate and Tropical lakes. This system was modified by G. C. Whipple (1927) by subdividing the three main types into three orders. In $1936 \mathrm{~S}$. Yoshimura improved the classification of Forel and recognized five types of lakes on the basis of thermal characteristics (Tropical, Subtropical, Temperate, Subpolar and Polar lakes). G. E. Hutchinson [1] considered the variation in latitude, altitude and depth of basin and recognized five categories of lakes (Amictic, Monomictic, Dimictic, Oligomictic and Polymictic). Lakes are often classified on the basis of availability of nutrients and productivity into three categories viz. Eutrophic, Oligotrophic and Dystrophic.

India occupying $9^{\text {th }}$ position in terms of freshwater biodiversity is a megadiverse in ichthyofauna.

In North Bihar Gandak basin, a total water spread area of more than 7000 ha are available of which $80 \%$ fall under old Champaran (East and West) district.

East Champaran district is situated in the plains of river Gandak, Burhi Gandak and Baghmati and came into existence as one of the district of State of Bihar in 1971. It occupies an area of $3968.0 \mathrm{~km}^{2}$. Nepal forms its northern boundary, Muzaffarpur southern while 
Sitamadhi and Sheohar eastern and West Champaran with part of Gopalganj bounds it in western side.

The history of lakes of Champaran district dates back of more than hundred years. The origin of lake is a complex phenomenon and they have been originated after the great flood of 1867 A.D. in Burhi Gandak, involving many natural and human forces, which inundated the entire basin, leaving a few isolated islands. The Gandak basin comprises a number of ' $U$ ' shaped natural impoundments, originated due to fluviatile activity of Burhi Gandak and its tributaries.

The Champaran district is bestowed with many perennial rivers, originating from Nepal and among them the Gandiki river also famous as the Gandak and Narayani is most significant. The main stream of river Gandiki enters into Nepal through Mustang canyon located in the Himalaya. Burhi Gandak (Sikrahana) is the most significant river associated in the creation of lakes in Gandak basin. Prior to the construction of embankment on either side of the river Burhi Gandak, it changed its courses invariably leading to the formation of meanders, which cut off partially or fully from the original rivers and assumed the shape of lakes.

Lakes have been the subject of numerous investigation all over the world, however, comparatively few studies are available from India in general [3-5] and North Bihar in particular [6,7]. This report is the first detailed ichthyofaunal study of a natural threatened lake of East Champaran district of North Bihar.

\section{Materials and Methods}

The Sugaon lake lies between $26^{0} 16^{\prime} \mathrm{N}$ Latitude and $84^{0} 30^{\prime}$ to $85^{0} 10^{\prime}$ E Longitude. It is located about $19.5 \mathrm{~km}$ south of Motihari town the headquarter of East Champaran district. During course of investigation fish specimens were collected using different kinds of fish appliances and devices with the help of local fishermen. The identification of fishes are based on Day [14], Talwar., et al. [8] and Mishra [9]. The nomenclature of various species are based on recent revisions. Fishing methods were observed and different informations related to lake, fishery and its management were gathered through various sources.

\section{Results and Discussion}

Man has exploited lakes from time immemorial. Lakes are formed on the surface of earth due to various natural mechanisms. Lakes differ widely in their origin, shape, size, depth, hydrobiology and other characteristics. Lakes has variously been defined (Table 1) by different scientists $[2,15]$.

\begin{tabular}{|c|c|}
\hline Scientists & Definition \\
\hline F. A. Forel & $\begin{array}{c}\text { A Body of standing water occupying a } \\
\text { basin and lacking continuity with sea }\end{array}$ \\
\hline R. A. Muttkowskii & $\begin{array}{r}\text { Those bodies of standing water which are } \\
\text { considerable expanse and deep enough to } \\
\text { stratify thermally }\end{array}$ \\
\hline P. S. Welch & All large bodies of standing water \\
\hline Johnes., et al & $\begin{array}{c}\text { Bodies of water, both natural and man- } \\
\text { made greater than two hectare in area }\end{array}$ \\
\hline
\end{tabular}

Table 1: Definition of Lakes.

The East Champaran district has a chain of 28 lakes running through the centre of the district. It occupies a water area of 7486 acres and shows a large potential for fishery development. Distribution and area of some important existing lakes in Gandak basin of East Champaran has been given in (Table 2).

\begin{tabular}{|c|c|}
\hline Name of Lakes & Area in ha \\
\hline Chaknaha & 400 \\
\hline Pipra pakri & 400 \\
\hline Bakaya & 160 \\
\hline Kararia & 120 \\
\hline Motijheel & 100 \\
\hline Turkaulia & 100 \\
\hline Sugaon & 80 \\
\hline Phulwaria & 80 \\
\hline Sirsa & 80 \\
\hline Chilraon & 80 \\
\hline
\end{tabular}

Table 2: Distribution and area of some important lakes of East Champaran.

Sugaon lake occupies an area of 80 ha (Figure 1-3). Its depth varies from 3 to 20 feet and sufficient quantity of water remains in the lake throughout the year, never entirely dries up.

During course of investigation altogether 41 species of inland fishes belonging to 24 genera, 15 families and 8 orders have been recorded (Table 3). 


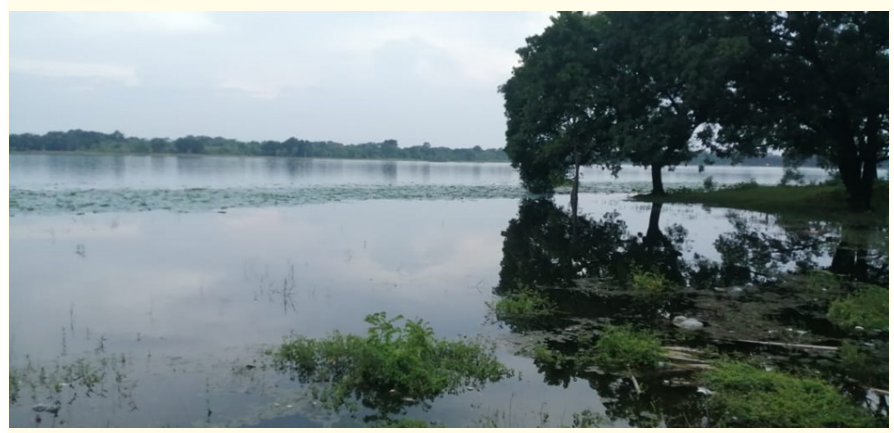

Figure 1: A general view of the Sugaon Lake.

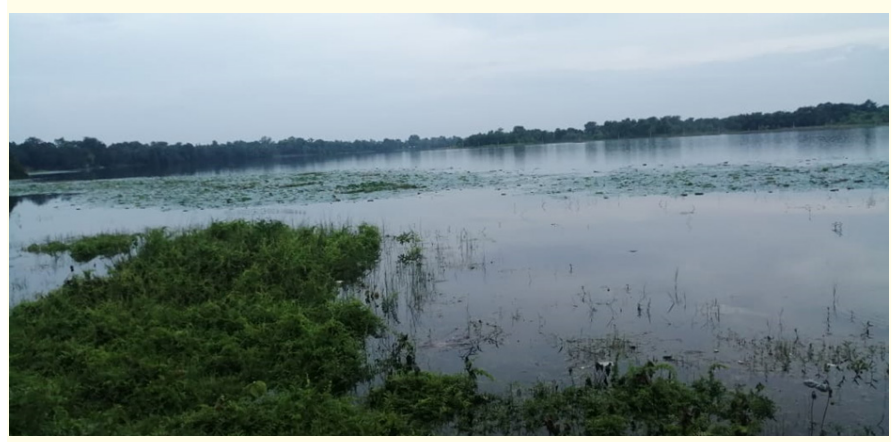

Figure 2: Aquatic macrophytes along the margines of the Sugaon Lake.

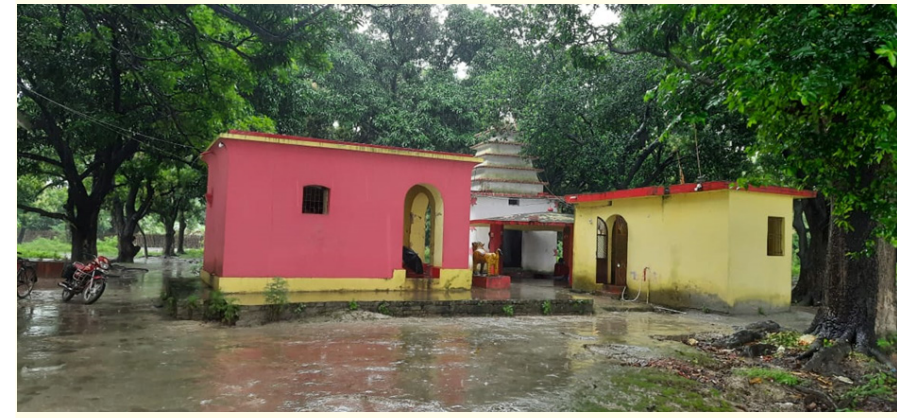

Figure 3: A temple for cultural activities on the margin of the lake.

The fishery of this lake is dominated by medium sized fishes (40\%) like Mystus cavasius (Ham.), Clarias batrachus (linnaeus), Notopterus spp., Channa spp., and Mastacembelus armatus (Lacepede) and big fishes like Wallago attu (Schneider) followed by miscellaneous fishes (55\%) like Chela laubuca (Ham.), Esomus danricus (Ham.), Barilius spp., Puntius spp., Xenentodon cancila (Ham.),Chanda nama (Ham.), Anabas testudineus (Bloch), Colisa fasciatus (Schneider). Miscellaneous fishes of less economic value have occupied the niche on a large scale, provided the basis for survival to the fishermen community of the area. The availability of the economic valued prized fish like Catla catla (Ham.), Aspidoparia morar (Ham.), Labeo spp., Cirrhinus spp., Clarias batrachus (Linnaeus) and Heteropneustes fossilis (Bloch) is much low about

\begin{tabular}{|c|c|c|c|c|}
\hline Order & Family & Genus & Species & Common Name \\
\hline Clupeiformes & Engraulidae & Setipinna Swainson & $\begin{array}{l}\text { Setipinna phasa } \\
\text { (Ham.) }\end{array}$ & Phansi \\
\hline \multirow[t]{17}{*}{ Cypriniformes } & Cyprinidae & Catla Valenciennes & Catla catla (Ham.) & Bhakur \\
\hline & & Chela Hamilton & Chela laubuca (Ham.) & Chelwa \\
\hline & & Esomus Swainson & Esomus danricus (Ham.) & Dendua \\
\hline & & Aspidoparia Heckle & Aspidoparia morar (Ham.) & Chippuah \\
\hline & & Barilius Hamilton & Barilius bola (Ham.) & Dhawai \\
\hline & & & Barilius bendelisis (Ham.) & \\
\hline & & \multirow[t]{2}{*}{ Puntius Hamilton } & Puntius ticto (Ham.) & Kotree \\
\hline & & & Puntius sarana sarana (Ham) & Durhi \\
\hline & & & Puntius chola (Ham.) & Sidhari \\
\hline & & & Puntius conchonius (Ham.) & Sidhari \\
\hline & & & Puntius sophore (Ham.) & Potiah \\
\hline & & Labeo Cuvier & Labeo bata (Ham.) & Bata \\
\hline & & & Labeo reba (Ham.) & Reba \\
\hline & & & Labeo calbasu (Ham.) & Kalbasu \\
\hline & & & Labeo gonius (Ham.) & Kursha \\
\hline & & & Labeo rohita (Ham.) & Rohu \\
\hline & & Osteobrama Heckel & Osteobrama cotio cotio (Ham.) & Goordah \\
\hline
\end{tabular}




\begin{tabular}{|c|c|c|c|c|}
\hline & & \multirow[t]{2}{*}{ Cirrhinus Oken } & Cirrhinus reba (Ham.) & Rewa \\
\hline & & & Cirrhinus mrigala (Ham.) & Naini \\
\hline & Cobitidae & Lepidocephalus Bleeker & Lepidocephalus guntea (Ham.) & Nakati \\
\hline \multirow[t]{7}{*}{ Siluriformes } & \multirow[t]{4}{*}{ Bagridae } & \multirow{4}{*}{ Mystus Scopoli } & Mystus bleekeri (Ham.) & Tengra \\
\hline & & & Mystus cavasius (Ham.) & Tengra \\
\hline & & & Mystus tengra (Ham.) & Tengra \\
\hline & & & Mystus seenghala (Ham.) & Tengra \\
\hline & Siluridae & Wallago Bleeker & Wallago attu (Schneider) & Boyari \\
\hline & Claridae & Clarias Scopoli & $\begin{array}{l}\text { Clarias batrachus } \\
\text { (Linnaeus) }\end{array}$ & Mangur \\
\hline & Heteropneustidae & Heteropneustes Miiller & Heteropneustes fossilis (Bloch) & Singhi \\
\hline \multirow[t]{2}{*}{ Osteoglossiformes } & \multirow[t]{2}{*}{ Notopteridae } & \multirow[t]{2}{*}{ Notopterus Lacepede } & Notopterus chitala (Ham.) & Moya \\
\hline & & & Notopterus notopterus (Pallas) & Golhi \\
\hline Atheriniformes & Belonidae & Xenentoden Regan & Xenentoden cancila (Ham.) & Kawwa \\
\hline Channiformes & Channidae & Channa Scopoli & $\begin{array}{c}\text { Channa striatus (Bloch) } \\
\text { Channa punctatus (Bloch) } \\
\text { Channa gachua (Ham.) } \\
\text { Channa marulius (Ham.) }\end{array}$ & $\begin{array}{c}\text { Sauri } \\
\text { Gauri } \\
\text { Chanaga } \\
\text { Sauri } \\
\end{array}$ \\
\hline \multirow[t]{4}{*}{ Perciformes } & Chandidae & Chanda Hamilton & Chanda nama (Ham.) & Chanda \\
\hline & Gobiidae & Glossogobius Giil & Glossogobius giuris (Ham.) & Bulla \\
\hline & Anabantidae & Anabas Cuvier & Anabas testudineus (Bloch) & Kawai \\
\hline & Belontidae & Colisa Cuvier & Colisa fasciatus (Schneider) & Kotra \\
\hline Mastacembiliforms & Mastacembelidae & Mastacembelus Scopoli & $\begin{array}{c}\text { Mastacembelus armatus } \\
\text { (lacepede) }\end{array}$ & Bami \\
\hline
\end{tabular}

Table 3: Fish fauna of Sugaon lake.

$5 \%$ only. Overall species composition of the lake showed the dominance of predatory and weed fishes. These fishes compete with major carps for food $[10,11]$. Inspite of the fact that lake of plains have a high rate of primary production, the present investigation showed a tremendous decrease in the ichthyofaunal diversity of the lake. Fishing is carried out by local fisherman of the primary fisherman Co-operative society. The fishing craft used were medium sized plank - built canoes. The gear employed were drag and cast nets. The lakes of Gandak basin are largely public properties brought under the state Department of fisheries and are auctioned annually to the local fisherman Co-operative societies. There is no export of fish from any of the fish markets of East Champaran district. This lake is subjected to considerable human pressure. Surrounding settlements are totally dependent on this lake for bathing , cloth washing, open defecation, cultural activities etc. Fishing is the greatest simple economic activity depended upon by the communities surrounding the lake and it is one of the greatest threats to biodiversity.

Lake management objectives includes maintenance of water quality, reduction of erosion, protection from flood, a buffer zone between human settlement and the lake, maintenance of a gene pool of plants and animals, controlled insect pest population, produced renewable resources and provided aesthetic support for human beings [12]. Various conservation measures as management tools for lakes includes reforestation, control of grazing on the slopes which are prone to soil erosion, to change the agriculture practice, to reduce the non- point pollution from the source [13]. The specific goals of the management of the lake may be listed as follows: Control of encroachments in the lake area and to stop large scale reclamations of the foreshore by filling and land leveling, sewerage system, control of siltation and sedimentation, increase of water circulation, over exploitation/fishing, law enforcement, public awareness, regular environment monitoring and making the fisheries co-operatives viable, eradication of predatory and weed fishes, measures to prevent entry of different riverine fish along with their spawn into the lake and strengthening of the mechanism of technology transfer.

\section{Conclusion}

The condition of Sugaon lake, in terms of fish and fisheries, is gradually becoming critical under the impact of anthropogenic 
pressures, fast pace of development, global warming, eutrophication, exotic species and subsequent modification of the river basins. Fish production from this lake could be modestly enhanced upto 3-4 times, if managed on the line of culture based capture fishery techniques with rational stocking of suitable species, size, density, and proper harvesting.

\section{Conflict of Interest}

No.

\section{Bibliography}

1. Hutchinson HE. "A tretise on Limnology, Geography, Physics and Chemistry". John Wiley and Sons, New York 1: (1957): 1015.

2. Gupta SK., et al. "General and Applied Ichthyology (Fish and Fisheries)". S. Chand and Company Ltd. Ramnagar. New Delhi. (2006): 559-588.

3. Pati DK. "Status of fish and fisheries of Ansupa lake, Orissa". Journal of the Inland Fisheries Society of India 40 (2008): 8384.

4. Prakasam, V.R., et. al., "Water quality of Sasthamkotta Lake, Kerala”. In Nair C.K.G.: (ed.). Proceeding of the National Seminar on Ecology and Conservation of Wetlands. Limnological Association of Kerala, Kerala (2002): 59-63.

5. Wani OA., et al. "A study on ichthyofaunal diversity of Sagar Lake, Madhya Pradesh, India". International Journal of Biodiversity and Conservation 7.3 (2015): 126-129.

6. Sinha M., et al. "Ecology and Fisheries of Ox-Bow lakes (Maun) of North Bihar - A threatened ecosystem". Central Inland Capture Fiseries Research Institute (ICAR), Barrakpore, W. Bengal. 74 (1997): 65 .

7. Chaudhary SK., et al. "Hydrobiological studies of the Bahandei reservoir of Basopati, Madhubani district of Bihar, India with references to its management". Ecology, Environment and Conservation 16:4 (2010): 513-517.

8. Talwar PK., et al. "Inland Fishes of India and Adjacent countries". Oxford and IBH Publication Co. Pvt. Ltd., New Delhi., 1 (1991): 2.

9. Mishra SK. "Hill Stream Fishes Along the Indo-Nepal Border". Mittal Publication, New Delhi (2012).
10. Nataranjan AV., et al. "The food Spectrum of trash fishes in relation to major carps in Konar and Tilaiya reservoir (Bihar)". Journal of the Inland Fisheries Society of India 7 (1975): 65-75.

11. Kumar, D. "study on abundance and behavious of weed fishes in Ravishankar reservoir (Madhya Pradesh)". In Vass K.K. And Sinha, M. (Eds). Changing Perespective of Inland Fisheries, Inland Fish, Soc. India, Barrackpore (1997): 143-149.

12. Pandik AK. "Dal Lake Ecosystem in Kashmir Himalaya, Ecology And Management". In Ecology and Pollution of Indian Lakes and Reservoir. Mishra, P.C. and Trivedi, R.K. (ed.) Ashish Publishing House, New Delhi. (1993): 131-202.

13. Jorgensen SE. "Introduction of Guidelines of Lakes Management. Lake Shore Management" (ed. S.E. Jorgensen and H. Loffler) International Lake Environment Committee Foundation and UNEP, Japan. 3: (1990).

14. Day F. "The Fishes of India: being natural history of the fishes known to inhabit the seas and freshwaters of India, Burma and Ceylon". Taylor and Francis, London (1875-1878): 778.

15. Johnes PB., et al. "Lakes - classification and Monitoring". Environment Agency, R and D Note 253, Environment Agency, R\&D Note 253, Environment Agency, Bristol (1994).

\section{Volume 3 Issue 11 November 2021 \\ (C) All rights are reserved by Safal Kumar Mishra., et al.}

